\title{
BUILDING MILLENNIALS GENERATION CHARACTER THROUGH CIVIC EDUCATION TO FACE THE ERA OF GLOBALIZATION
}

\author{
Nurul Fadilah ${ }^{1}$; Moses Glorino Rumambo Pandin ${ }^{2}$ \\ ${ }^{1,2}$ English Literature Department, Faculty of Humanities, Airlangga University \\ nurul.fadilah-2020@fib.unair.ac.id; moses.glorino@ fib.unair.ac.id
}

\begin{abstract}
Background: The rapid flow of globalization makes the world free from barriers so that the existence of globalization gives birth to a new concept of "World Without Borders". This situation puts the character of millennials on the brink of collapse and needs to be straightened out. Based on the problems above, the researcher determines the question: How is the role of civic education in shaping millennial character in the era of globalization? Purpose: The purpose of this study is to determine the impact of the current globalization on society, as a form of knowledge of the importance of citizenship education as a shield in the era of globalization, knowing the role of civic education in shaping the character of the millennial generation. Method: The method used in this research is literature review. The search for journals was carried out using the google scholar database with the keywords "citizenship educations", "millennial generation", and "globalization". Feasibility studies are assessed based on title, abstract, and full text. Data analysis using qualitative analysis based on research findings. Results: The results of this study show the influence of globalization causes character problems in millennials increasing every year. The high nature of individualism, consumerism, and westernization shows the characteristics of Indonesia began to erode and eventually also impacted the moral damage. Therefore, prevention is necessary through citizenship education as the basis for character formation by the values of Pancasila.
\end{abstract}

Keywords: millennials, citizenship education, globalization

\section{INTRODUCTION}

Currently, Indonesia has entered the era of globalization, where it is characterized by the ease of people getting information from various parts of the world due to the rapid development of technology and science. According to Budiarto(1) Globalization itself has the understanding of the formation of unification of society around the world (global) because of technological and communication advances that can shorten interactions between regions with each other. The impact of globalization makes the world more open and interdependent between countries. In other words, globalization brings a new view of the concept of "World Without Borders" which until now became a reality and impacted the character of millennials. The problems that arise due to globalization on society, especially for the millennial generation are the lack of awareness that "human beings are social beings", this is because people feel facilitated by the existence of advanced technology so that they feel they do not need others who eventually give birth to 
individualism. Globalization also affects the lives of millennials, namely consumerism, which can lead to hedonism. It is also not per the norms imposed in Indonesia. In addition, the emergence of westernization influences or patterns of life that always imitate western cultural styles such as dress styles, behaviors, and cultures that are contrary to existing values and norms become a striking influence of globalization.

Various challenges arising from the current globalization of the character of millennials become a challenge and a great threat that can not be left alone. Globalization brings changes that are incompatible with existing values and norms towards the character of millennials. "Character refers to a series of attitudes, behavior, motivation, and skills"(2). It is concerning to forget the identity of the Indonesian nation to become a good citizen. This is the main reason researcher conduct research on changes in millennial character due to globalization and overcoming problems with character education through civic education. This research needs to be done to minimize the damage to the character of the millennial generation due to the influence of globalization.

Thus, in preparing the character of millennials to meet the era of globalization, it is necessary to be equipped with an understanding of citizenship education. According to Asyari(3) Citizenship Education is oriented to foster the concept of national status and is also implemented in daily life. This is the basis for the nation and country to foster millennials who are characterful, intelligent, and good amidst the rapid flow of globalization. Previous research by Lusiana Rahmatiani(6) stated that the formation of national character through citizenship education is a must because it can form a bright young generation who also has a noble character so that their existence in social life becomes meaningful and has character. Based on the background of the problems that have been stated above, the researcher determines the research question: What is the role of civic education in shaping the character of the millennial generation? Thus, this study explores the role of civic education in shaping the character of the millennial generation.

\section{METHOD}

The writing of this article uses the method of study library (literature review), where researchers use/search for references sourced from journals and books. This research activity was conducted to collect information data relevant to the topic or problem that became the object of the study or research(4). By conducting a literature review, researchers can utilize all information and thoughts relevant to the topic of this study. Literature searches were carried out on the database 
electronic Google Scholar using the keywords "Citizenship Education", "Millennial Generation" and "Globalization".

This study uses qualitative analysis to obtain in-depth data from the literature review using the available theoretical framework. On pages 163-164 of the book "Qualitative \& Quantitative Research Methods": The entire data is classified based on the needs of the coding process. The final stage in this method is data interpretation. Interpretation step to analyze data to produce the required information (12). Based on the results of the search, found as many as 95 articles. Then filtering is carried out based on the similarity of the title $(n=95)$, abstract $(n=30)$, and the completeness of the text $(n=10)$ to suit the required information. The study was conducted based on the eligibility of the inclusion criteria and obtained 10 articles used in the literature review.

\section{RESULTS}

Based on the analysis in table 3, the impact brought by the rapid globalization flows causes character problems to increase such as high individualism, consumerism, and westernization. In 2017 the attitude of individualism was only $30 \%$, but the rapid advancement of technology due to globalization has made people, especially the millennial generation, think that their lives have been fulfilled and consider other people unimportant. So that the increase in individualism is inevitable for the last 3 years, and will reach $80 \%$ by $2020(5)$. On the other hand, consumerism has recently started to attack society, especially the millennial generation. The increase that occurred every year starting from 2017: $35 \%$ jumped up to $83 \%$ in 2020. The cause of the increase in consumerism was due to the desire to always be updated. The influence of westernization makes the millennial generation regard consumerism as an act of modernization(2)(5). Westernization is also the result of globalization. This is evidenced by the fact that the millennial generation of the Indonesian nation imitates many westernized styles and considers western culture as a trend that must always be followed so that the label "conservative" does not stick to itself and forgets its identity as the Indonesian nation(3). The percentage of westernization shows that westernization is one of the most striking effects of globalization(5). The existence of westernization causes a high consumptive lifestyle for the community, especially the millennial generation, by always consuming goods from abroad, this results in the emergence of hedonism(2). $50 \%$ of perpetrators are children under the age of 20 , where $30 \%$ of the perpetrators are junior high and high school adolescents(5). 
Based on the analysis in table 4, the damage to the character of the millennial generation also has an impact on the moral condition of the millennial generation, such as harassment, rape, and drug abuse. The increase in moral cases every year continues to show a high increase. Every month the increase in harassment cases can increase by $6 \%$ and rape cases, there are at least 4 cases that need to be handled in a week(1). Drug abuse increases by 2 tonnes annually. 2.6 percent of junior high school students and their equivalent have used drugs, and 4.7 percent of high school students have ever used drugs(5). This is evidenced by the percentage increase that occurred in 2017: harassment $40 \%$, rape $30 \%$, and drug abuse 35\%. In the last three years, moral cases have increased until 2020: 75\% abuse, 85\% rape, and 89\% drug abuse(1)(5). In this case it was found that 50\% of the perpetrators were junior and senior high school youths. The cause of the high moral cases is caused by character damage due to globalization. Advances in technology make it easy for teenagers to access the internet. Lack of understanding of character education makes adolescents unable to filter the impact brought about by globalization(4). Most of the perpetrators of moral cases are committed by junior high and high school teenagers with consensual reasons, a sense of curiosity to try, and a lack of parental supervision.

The deviation of the character makes it seem as if Indonesia has no effort to filter the impact of globalization. So the damage to the character of the younger generation is inevitable. Therefore, citizenship education is recommended as a suggestion to form a good character. Because citizenship education not only teaches about the management of the state but also about how to have good citizens and by Pancasila and the 1945 Constitution(6). Character education can be denied through citizenship education. Citizenship education plays an important role in the formation of the character of millennials to minimize character problems in Indonesia caused by the current globalization.

Implementation of state education as character education can be done through learning planning, namely in the syllabus and RPP character(7). Character development is also obtained through school culture such as values, norms, and attitudes can influence the mindset and character of the younger generation(5). Character building is also influenced by community participation. The community as evaluators will later give criticism and advice to others(1). Thus, the character resulting from the implementation of character education through the learning of Citizenship Education is a character following Pancasila and the 1945 Constitution, especially the character of 
discipline(8). Because the purpose of Citizenship Education is basically to create learners into democratic citizens and character by the values of Pancasila(8)

\section{DISCUSSION}

\section{The Impact of Globalization}

Currently, Indonesia has entered the era of globalization, where it is characterized by the ease of people getting information from various parts of the world due to the rapid development of technology and science. The era of globalization is also supported by the rise of the digital era where all the development of life becomes all digital and facilitates people in doing anything(5). However, such circumstances also harm the continuity of the character of millennials. In the era of globalization, people are required to transform in various aspects of life. In other words, anyone who does not want to change, then he will be run over by the change itself. This is in line with Sholahudin's opinion(4) on socialization, citing the opinion of A. Giddens, whether good or bad, we are driven into a global order that is not fully understood by anyone, but the impact can be felt by all of us. The impact of globalization makes the world more open and interdependent between countries. This means that globalization brings a new view of the concept of "World Without Borders" which until now became a reality and impacted Indonesia in the structure of people's, national, and state life. All of that will influence the thinking and attitudes/character of millennials who are the hope of the next generation of the nation.

Globalization is essentially a process of proposing ideas that are then followed by other countries, the country finally reaches a mutual agreement and becomes a common guideline for countries in the world(3). This makes the problem of character in Indonesia tips sticking out. The high attitude of individualism - selfishness and considering others insignificant to cause indifference - proves that Indonesia's characteristics as a friendly society are beginning to be scratched due to globalization. In addition to the decline of consciousness of "human beings are social beings", globalization also influences the lives of millennials, namely consumerismextravagant lifestyle attitudes or behaviors, where goods or services are overused, resulting in hedonism - which is not following the norms imposed in Indonesia. Hedonism can cause divisions due to selfishness to achieve pleasure. The influence of westernization is also a real impact of globalization. patterns of life that always imitate western cultural styles such as dress styles, behaviors, and cultures that deviate from the state of values and norms that exist in Indonesia. The 
inclusion of western culture that is no longer filtered by millennials, makes millennials on behalf of it as modernity (1). In addition to threatening the damage to the character of millennials, westernization also has an impact as a decrease in the sense of nationalism among millennials. All of that will weaken the identity of millennials as Indonesians.

Character damage has an impact on moral damage that needs to be considered as well. The powerful influence of globalization can quickly affect millennials. This is a very unfortunate subject considering millennials as determinants of the progress of the Indonesian nation. Morale cases continue to increase as the years go by. The increase proclaims that a lack of understanding of civics education as the foundation of character building for millennials. Based on the exposure of the above results, the moral case seems familiar amid the current globalization, and as if it is the impact of globalization. Sholahudin(4) revealed that the theorists of globalization stated, every country and anywhere can not avoid and turn away from the current globalization which is a continuation of the ideology of developmentalism (ideology of development) that adopts modernization theories. Therefore, it is very important to implement and realize character building - as a filter for the entry of globalization - through citizenship education. In this case, citizenship education has an important role as part of the formation of the character of millennials by Pancasila and the 1945 Constitution.

\section{The Role of Citizenship Education for Character Building}

Character is a person's character, character, morals, or personality which is formed from the internalization of various virtues which are arranged and used as a basis for point of view, thinking, acting, and acting(6). Characters are divided into two, namely positive characters and negative characters. A person's character can be seen through how individuals think, act, and are responsible. Character building can be obtained through character education. According to (Shenfield, 2016, Putra, 2017; White \& Shin, 2017) in the Rinita Rosalinda Dewi, Edi Suresman, Cik Suabuana's article(7) character education is a conscious and planned effort through a learning environment that aims to encourage the growth and development of all human potential, so that it has a good personality and character, and has a good impact on nature and society. Character education can also be interpreted as a guidance process that helps grow, develop, mature, and shape a person's personality which is a person's traits or character(7). Character education is a good guidance for adolescents as the younger generation who support the development and development 
of the country. Adolescence is very vulnerable, so it is necessary to make efforts to shape the character of adolescents to become a figure that fits the expectations of the nation, who will replace the senior generation in the future(9) In this connection, Rahmatiani (6) argues that education that directs the goal of character orders, one of which is civic education. Citizenship education has become an inherent part of the national education instrumentation to educate the Indonesian nation through the corridor of "values-based education".

Citizenship education according to the Ministry of National Education (2006) in Rahmatiani's research(6) is a subject that focuses on the formation of citizens who understand and can exercise their rights and obligations to become smart, skilled, character Indonesian citizens mandated by Pancasila and the Indonesian Constitution. 1945. Learning civic education is learning about Indonesia. In other words, learning to be Indonesian is fully following Pancasila and the 1945 Constitution, which can defend Indonesia's identity despite the continuing threat of globalization and loves the homeland and the Indonesian nation. The implementation of civic education as character education can be carried out through learning planning, namely in the syllabus and RPP (lesson plans) with character(7). Where in the RPP (lesson plan) there needs to be 3 main components that must be mastered in civic education. This is in line with Margaret Stimman Branson's opinion in an article entitled The Role of Civic Education (1998), 3 main components need to be mastered in learning Citizenship Education, namely civic knowledge, civic skills, and civic disposition. national character)(10). The formation of the character of the millennial generation must have three main components of civic education as mentioned by Margaret Stimman Branson in the article Setiawati and Dewi. Millennials who have the knowledge and attitude of citizenship will become confident individuals (civic confidence). Millennials who have civic knowledge and skills will become capable individuals (civic competence). Finally, millennials who have civic attitudes and skills will become committed individuals(10). In the end, the millennial generation who has the knowledge, attitudes, and skills of citizenship will become smart and good citizens. In this case, citizenship education is expected to be a bridge in the formation of the character of the millennial generation that has been eroded by the changing era.

As a subject, citizenship education contributes to the formation of self-development. Citizenship education includes not only materials, but also the right way to foster the morality and attitudes of generations in daily life both in the family, school, and community environment(10). Citizenship education has an important role in training citizens, especially millennials as the 
successor of the nation to raise awareness of the defense of the country and increase the sense of nationalism or love of the homeland as a shield from changes due to globalization. Through citizenship education, millennials are expected to understand, analyze and answer the problems faced by society, nation, and country(6).

According to Asyari(3) Citizenship Education is oriented to foster the concept of national status and is also implemented in daily life. So that the existence of citizenship education is to foster the younger generation to have good character. Damri and Putra(11) state that citizenship education has a purpose as the table below.

Table 1: Purpose of Citizenship Education

\begin{tabular}{|l|l|}
\hline General Purpose & $\begin{array}{l}\text { 1) Supporting the success of national educational achievement, namely } \\
\text { "educating the life of a nation that develops the whole Indonesian people. } \\
\text { Namely, people who believe and fear God Almighty and have noble } \\
\text { ethics, have the ability of knowledge and skills, spiritual physical health, } \\
\text { personality of a democratic society". } \\
\text { 2) Provide basic knowledge and skills to learners about the relationship } \\
\text { between citizens and the state and basic education of defense to become } \\
\text { a reliable citizen by the nation and the country. }\end{array}$ \\
\hline Special Purpose & $\begin{array}{l}\text { Fostering morals that are expected to be realized in daily life are: } \\
\text { 1. Behavior that radiates faith and piety to The One True God } \\
\text { 2. Fair and civilized human behavior } \\
\text { 3. Behavior that favors populism that places public interest above } \\
\text { the interests of individuals } \\
\text { 4. Behavior that supports efforts to realize social justice for all } \\
\text { Indonesians } \\
\text { The special purpose for learners to: } \\
\text { 1. Understand and carry out the rights and obligations in a polite, } \\
\text { honest, democratic and sincere manner as an educated and } \\
\text { responsible citizen } \\
\text { Mastering and understanding various basic problems in the life of } \\
\text { society, nation, and state and can overcome them with critical and } \\
\text { responsible thinking based on Pancasila, Nusantara insights, and } \\
\text { national resilience } \\
\text { Have attitudes and behaviors that are following the values of } \\
\text { struggle, love of the homeland, and willingness to sacrifice for the } \\
\text { nation }\end{array}$ \\
\hline
\end{tabular}

To achieve this goal, citizenship education cannot stand on its own but must collaborate with school learning and culture strategies that support character development. So that the culture 
that exists in the school such as values, norms, and attitudes can influence the mindset and character of the younger generation(5). Character building is also influenced by community participation. The community as evaluators will later give criticism and advice to others(1). In addition, Setiawati and Dewi(10) suggest that several characters become the benchmark of character development, such as the following table

Table 2: Characters that become the benchmark

\begin{tabular}{|c|c|}
\hline $\begin{array}{l}\text { Characters that become } \\
\text { the benchmark }\end{array}$ & Means \\
\hline Religion & $\begin{array}{l}\text { Religion is an attitude of obedience to the religious doctrines it } \\
\text { adheres to but does not disparage other religions. It is expected that } \\
\text { by having a religious character, millennials can form values, ethics, } \\
\text { and moral foundations in achieving. }\end{array}$ \\
\hline Honesty & $\begin{array}{l}\text { Honesty is based on the behavior of making yourself a trustworthy } \\
\text { person in words, actions, and work. Millennials need to have an } \\
\text { honest attitude toward themselves. }\end{array}$ \\
\hline Responsibility & $\begin{array}{l}\text { Responsibility is a form of responsibility in every action taken, } \\
\text { which will indicate that the person must be disciplined and can bear } \\
\text { the consequences of his actions. }\end{array}$ \\
\hline Tolerance & $\begin{array}{l}\text { Tolerance is an attitude and action that values difference. Tolerance } \\
\text { will make it easier for individuals and groups to communicate with } \\
\text { each other without discrimination. }\end{array}$ \\
\hline Discipline & $\begin{array}{l}\text { Discipline complies with any applicable rules or regulations. This } \\
\text { shows that these millennials respect and abide by the agreed rules. }\end{array}$ \\
\hline Strive & $\begin{array}{l}\text { Hard work is to strive in every action, independent, optimistic and } \\
\text { assertive will show that millennials are people of character and } \\
\text { worth working with. }\end{array}$ \\
\hline Creative & $\begin{array}{l}\text { Creative is thinking creatively and critically will show as an } \\
\text { intelligent person. This will avoid plagiarism and give rise to } \\
\text { something more innovative. }\end{array}$ \\
\hline Democratic & $\begin{array}{l}\text { Democratic is a way of thinking, behaving, and acting that judges } \\
\text { equally between the rights and obligations of himself and others. } \\
\text { Know what is more important and what to take precedence over. }\end{array}$ \\
\hline
\end{tabular}




\begin{tabular}{|l|l|}
$\begin{array}{l}\text { The Spirit of Nationality } \\
\text { and Love of the } \\
\text { Motherland }\end{array}$ & $\begin{array}{l}\text { This attitude is necessary because there is no awareness, spirit of } \\
\text { nationality, and love of the homeland. If that attitude does not exist } \\
\text { in millennials, then as the successor of the younger generation, he } \\
\text { will not have good character. }\end{array}$ \\
\hline $\begin{array}{l}\text { Environmental and Social } \\
\text { Care }\end{array}$ & $\begin{array}{l}\text { A reflection of environmental and community awareness will bring } \\
\text { every millennial into a respected person, loved and protected by the } \\
\text { environment. }\end{array}$ \\
\hline
\end{tabular}

The implementation of character-building strategy through citizenship education, creating a superior millennial generation. The character of millennials formed such as 1) Millennials who are moral and well behaved; 2) Reach smart and rational millennials; 3) Millennials in the future are innovative generations and continue to pursue progress; 4) Strengthen the spirit and continue to find solutions in various difficulties 5) Millennials must be true patriots, love the nation, country and homeland(9).

Thus, citizenship education is a strategic way to shape the character of millennials. As one of the pillars of support in the formation of the character of millennials, which means citizenship education becomes a tool to direct citizens to be good citizens, smart citizens in facing the development of the world in the era of globalization in addressing social problems (6). The purpose of citizenship education is to build millennials who have a character following the values of Pancasila.

\section{CONCLUSION}

Globalization is the process of entry into the scope of the world. Technological advances make the world have a transparent partition so that the country seems without borders. The existence of globalization without accompanied by the strengthening of character for millennials led to the birth of a character that is not following the value of Pancasila. It also has moral damage among millennials. Therefore, prevention is necessary through citizenship education as the basis for character formation following the values of Pancasila.

Citizenship education is a subject that focuses on the formation of citizens who understand and can carry out their rights and obligations to become intelligent, skilled, characterful Indonesian citizens mandated by Pancasila and the 1945 NRI Constitution. Citizenship education is expected to reduce the high number of characters and moral damage to give birth to a generation of good 
character. Citizenship education has an important role in the formation of the character of millennials so that they can understand, analyze and answer the problems faced by society, nation, and country. Therefore, to face the challenges of globalization, millennials need to be equipped with an understanding of citizenship education early on to form a generation with Pancasila character.

\section{REFERENCES}

1. Budiarto G. Indonesia Dalam Pusaran Globalisasi Dan Pengaruhnya Terhadap Krisis Moral Dan Karakter. Pamator J. 2020;13(1):50-6.

2. Fitriani R, Dewi Da. Membangun Karakter Generasi Muda Melalui Implementasi NilaiNilai Pancasila Di Tengah Arus Globalisasi. J Ilmu Pendidik. 2021;3(2):514-22.

3. Asyari D, Dewi Da. Peran Pendidikan Kewarganegaraan Bagi Generasi Milenial Dalam Menanamkan Jiwa Nasionalisme Di Era Globalisasi. J Pendidik Dan Konseling. 2021;3(2):30-41.

4. Sholahudin U. Globalisasi : Antara Peluang Dan Ancaman Bagi Masyarakat Multikultural Indonesia Umar Sholahudin Program Studi Sosiologi Universitas Wijaya Kusuma Surabaya Globalization: Between Opportunities And Threats For. Sosiol Pendidik Humanis. 2019;4(2):103-14.

5. Sakman, Bakhtiar. Pendidikan Kewarganegaraan Dan Degradasi Moral Di Era Globalisasi. J Pemikir Dan Penelit Ilmu-Ilmu Sos Hukum, Pengajarannya. 2019;Xiv(1):01-8.

6. Rahmatiani L. Pendidikan Kewarganegaraan Sebagai Pembentuk Karakter Bangsa. In: Prosiding Seminar Nasional Kewarganegaraan. Yogyakarta; 2020. P. 87-94.

7. Dewi Rr, Suresman E, Suabuana C. Pendidikan Kewarganegaraan Sebagai Pendidikan Karakter Di Persekolahan. Asanka. 2021;2(1):79-90.

8. Mamelio A, Idris M, Dedy A. Implementasi Pendidikan Karakter Dalam Pembelajaran Pendidikan Kewarganegaraan Pada Peserta Didik Sdn 1 Ujung Tanjung. Wahana Didakt. 2021;19(1):31-7.

9. Primasari Dag, Dencik, Imansyah M. Pendidikan Karakter Bagi Generasi Masa Kini. In: Prosiding Seminar Nasional Pendidikan Program Pascasarjana. Palembang; 2019. P. 110018.

10. Setiawati R, Dewi Da. Hubungan Pengembangan Karakter Pada Peserta Didik Melalui Pendidikan Kewarganegaraan. J Pendidik Tambusai. 2021;5(1):897-903.

11. Damri, Putra Fe. Pendidikan Kewarganegaraan. Kesatu. Jakarta: Kencana; 2020. 285 P.

12. Hardani, Auliya NH, Andriani H, Fardani RA, Ustiawaty J, Utami EF, et al. Metode Penelitian Kualitatif \& Kuantitatif. kesatu. Yogyakarta: CV. Pustaka Ilmu Group Yogyakarta; 2020.515 p. 


\section{ATTACHMENT}

Table 3: Character corruption improvements(2)(3)(5)

\begin{tabular}{|c|c|c|c|c|c|c|}
\hline Year & Individualism & Because & Consumerism & Because & Westernization & Because \\
\hline 2017 & $30 \%$ & \multirow[t]{4}{*}{ technology } & $35 \%$ & \multirow{4}{*}{$\begin{array}{l}\text { Desire to } \\
\text { always } \\
\text { update }\end{array}$} & $40 \%$ & \multirow{4}{*}{$\begin{array}{l}\text { Consider } \\
\text { the } \\
\text { outside } \\
\text { culture } \\
\text { cool }\end{array}$} \\
\hline 2018 & $50 \%$ & & $45 \%$ & & $55 \%$ & \\
\hline 2019 & $65 \%$ & & $75 \%$ & & $70 \%$ & \\
\hline 2020 & $80 \%$ & & $83 \%$ & & $90 \%$ & \\
\hline
\end{tabular}

Table 4: Improved moral cases(1)(5)

\begin{tabular}{|c|c|c|c|c|c|c|}
\hline Year & Abuse & Perp & Rape & Perp & Drug Abuse & Perp \\
\hline 2017 & $40 \%$ & \multirow{4}{*}{$\begin{array}{l}50 \% \text { of } \\
\text { Indonesian } \\
\text { teens }\end{array}$} & $30 \%$ & \multirow{4}{*}{$\begin{array}{l}30 \% \text { of } \\
\text { junior } \\
\text { high and } \\
\text { high } \\
\text { school } \\
\text { students }\end{array}$} & $35 \%$ & \multirow{4}{*}{$\begin{array}{l}2.6 \% \\
\text { junior } \\
\text { high } \\
\text { school } \\
\text { and } 4.7 \% \\
\text { high } \\
\text { school }\end{array}$} \\
\hline 2018 & $45 \%$ & & $49 \%$ & & $50 \%$ & \\
\hline 2019 & $55 \%$ & & $70 \%$ & & $75 \%$ & \\
\hline 2020 & $75 \%$ & & $85 \%$ & & $89 \%$ & \\
\hline
\end{tabular}

